\title{
Localized practices and globalized futures: challenges for Alaska coastal community youth
}

\author{
Marie E Lowe
}

\author{
Correspondence: \\ mlowe@uaa.alaska.edu \\ Institute of Social and Economic \\ Research, University of Alaska \\ Anchorage 3211 Providence Drive, \\ Anchorage, Alaska 99508, USA
}

\begin{abstract}
Increasing enclosure in fisheries, the rising cost of living in northern rural areas, and the single sector economies of many coastal communities have increased community vulnerability to short and long-term resource and market instabilities. This article situates Alaska coastal youth within the current economic uncertainty experienced by communities traditionally reliant upon commercial fishing. Focus group interviews conducted with youth aged 16-24 in Gulf of Alaska coastal communities demonstrate youth in this region possess strong, place-based social capital shaped by the small size and geographic remoteness of their communities as well as a connectedness to each other and to the physical environment of those communities. Key discourses emerged in the interviews concerning this "close-knit" nature of Alaska coastal communities, how their residents are "hands-on" people in the context of employment preferences and affinities, and that Alaska coastal youth perceive a "real world" beyond the borders of their communities offering them attractive amenities of modern, urban lifestyles. As opportunities in traditional occupations such as fishing diminish, coastal youth are encouraged to pursue higher education and in this context, young women are leaving more frequently than young men as gender roles change. Interviewees report many youth who do leave, however, often return home without completing their education and how others who do must sometimes leave home permanently to pursue careers unavailable at home. Including a youth perspective in policy discussions concerning local economic development would produce the following prescriptions: 1) investing in training coastal youth for culturally relevant and desirable work, 2) recognizing youth might want to return to their home communities in the future, particularly with their families, 3) giving youth a voice in community affairs and policymaking to cultivate future community leaders and stewards, and 4) committing to economic development strategies that encourage local ownership in coastal resources and industries.
\end{abstract}

\section{Introduction}

For many of Alaska's coastal communities, current economic realities are defined by overcapitalization of fishing fleets, property rights based management regimes, dramatic fluctuations in both global fish and fuel prices, and the vagaries of a rapidly changing environment. Barriers to entry in fisheries are increasing, particularly for young people, resulting what is now colloquially referred to as the "graying of the fleet" (Rosvold 2007), or an aging fisheries workforce in many of Alaska's communities. Potential growth industries such as seafood processing operations, often controlled by non-local entities, move towards vertical integration and reliance upon imported labor (Lowe 2008). Eypórsson (1997) raises the question about how fisheries are becoming more efficient but for whom 
and at what geographic level? Increasing enclosure in fisheries, the rising cost of living in rural Alaska, and the single sector economies of many coastal communities have increased community vulnerability to short and long-term resource and market instabilities.

Through empirical research that qualitatively describes the lifeways of coastal community youth in the Gulf of Alaska region, this article situates youth aspirations within the context of current economic uncertainty experienced by Alaska communities traditionally reliant upon commercial fishing. Many young residents of Alaska coastal communities have been enculturated into a fishing lifestyle, a cultural and spiritual connection to the sea and its resources, and have a strong "sense of place" (Jones 1999; Eisenhauer et al. 2000) and a "social embeddedness" (McCay 2000) connected to their home communities. Their enculturated beliefs, values, and practices come into conflict, however, with barriers to upward mobility in traditional occupations and from new pressures from globalization of both markets and the fishing industry, accompanied by an associated expansion of the processing industry. There are potential opportunities for employment in the development of other Alaska coastal industries, i.e. tourism, shipping, and oil and gas industries but future, local contributions to these activities are uncertain and will likely be varied.

The first section of the article provides further context for the current changing economic and social conditions in Alaska's coastal communities. It presents an overview of outcomes of economic restructuring in fisheries and coastal industries with associated sociocultural and community effects. These effects are also examined in the context of other external forces associated with social change in coastal communities such as changing gender roles and expectations for youth to seek higher education. A description of the study communities follows, setting the stage for a discussion of key discourses that emerged in group interviews with youth about their lives today, their goals or aspirations for the future, and an examination of community in- and out-migration from their perspective. These discourses concern the "close-knit" qualities of social relations in Alaska coastal communities and an orientation towards "hands-on" and selfdirected employment preferences and affinities. Indicative of embodied local practices, these discourses exist alongside narratives illustrating increasing expectations for coastal youth to pursue higher education goals, the current gendered aspects of community out-migration, and other discourses addressing youth desire to experience "the real world" beyond the borders of their communities. Policy recommendations are discussed that attend to bridging the divide between local community based practices and anticipated globalized futures. They include: 1) investing in training coastal youth for culturally relevant and desirable work, 2) recognizing how out-migrating youth might want to return to their home communities in the future, particularly with their families, 3) giving youth a voice in community affairs and policymaking to cultivate future community leaders and stewards, and 4) committing to economic development strategies that encourage local ownership in coastal resources and industries.

\section{Cultural responses to socioeconomic change in fishing communities}

Many of the world's fisheries today are compromised by overcapitalization and overfishing as well as ecological challenges such as those arising from pollution and ocean acidification. Fisheries management entities have responded to these problems with market based approaches to increase efficiencies. The neoliberalization of marine and coastal industries, often accomplished through rights-based management programs and 
transnational corporate processor expansion, has resulted in loss of local jobs, a lack of entry level opportunities for young people, (Carothers 2008; Langdon 2008; Lowe 2008) and a concentration of wealth in the hands of existing owners of capital (McCay 1995; Mansfield 2004) whom, in the case of Alaska fisheries, often reside outside the state's localities. Contemporary studies in the social sciences have documented the substantial sociocultural effects of these economic restructuring outcomes and the challenges they pose to the future viability of fishing communities (McCay 1995; Pálsson and Pétursdóttir, eds. 1997; Lowe and Carothers, eds. 2008). Effects relevant to this study include the potential erosion of local social capital, loss of traditional social roles for young people to fill, increasing youth outmigration (particularly among young women), and the challenges in meeting the cultural capital requirements of a future life potentially lived outside the coastal community.

By introducing heightened levels of competition in the system, restructuring in fisheries can challenge the maintenance of local social capital in northern coastal communities (Jentoft 2000). Social capital, defined as instrumentally useful social relationships, connections, and networks (Froerer 2012) is produced as a result of family life and placed-based interactions and exchanges (Bourdieu 1986). It is a cultural feature common to rural, northern communities and arguably central to a rural youth's identity and well-being (Glendinning 2003). Social capital in rural communities is also invariably tied to an attachment to place (Elder et al. 1996; Pretty et al. 2006) - and in the northern context, is influenced by the community's natural environment and associated outdoor activities (Waara 2002; Wiborg 2003) in conjunction with connections to the family.

In Bourdieu's framework, social capital exists in the "durable networks" membership in a group requires that produce material and symbolic profits to the members (1997:51-52). To maintain these networks, "friendships fostered within a 'close-knit' community rely on recognizing and validating a shared habitus" (Ingram 2009:423). As the foundational concept at the center of Bourdieu's theory of practice, the habitus is defined as "a set of dispositions" (Bourdieu 1977) that Zipin et al. (2015) note:

...emerge and take shape through intimately lived practices and relations, embedded in the material and cultural conditions of given social-structural positions.

Particularly in early childhood environments of family and proximate settings, these dispositions become embodied...(2013:234).

In an Alaska coastal community reliant upon commercial fishing, that shared habitus is transmitted by enculturation processes in childhood that orient community youth towards a fishing lifestyle. Traditionally, children and young adults have always worked alongside adults in northern fishing communities (Paulgaard 2002). Northern, male, coastal youth learn to embody "rural masculinities" expressed via values and competencies gained through "practical knowledge" (Bye 2009) and multiple skills (Corbett 2004) integral to traditional livelihood pursuits such as fishing. Women's labor in fishing communities by contrast has been traditionally regarded as having less value, such as work in processing plants-as opposed to the "real" work of fishing (Jentoft 1993; Skaptadóttir 1996). However, women's labor and that of children in fishing families have always been important contributions to the overall enterprise of local, community based fisheries and maintenance of the community while men are at sea. (Nadel-Klein and Davis 1988; Skaptadóttir 2000; Karlsdóttir 2008). 
A traditional and marked division of labor between men and women is highly characteristic of many fishing communities in the industrialized world (Acheson 1981; Yodanis 2000; Paulgaard 2002) which contributes to deep gender inequalities (Skaptadóttir 1996). The high degree of gender stratification in fishing communities is exacerbated by fisheries industrialization (Skaptadóttir 1996) and fisheries restructuring (Dahlström 1996, Skaptadóttir 2000). By further forcing a shift from kin-based to contractual fishing businesses, fisheries restructuring and privatization processes only serve to bring gender based social divisions into relief and thereby create lasting impacts on coastal communities' social structure (Arbo and Hersoug 1997). The contributions of women and children to the community fishing economy are marginalized within modes of production characterized by high capital investments in vessels and gear, and in increasingly off-shore, intensive effort fisheries in which fishers are away from families and communities for longer periods of time.

The literature on Alaska rural communities and other circumpolar north regions demonstrates a growing dichotomy between the life experience of young men and young women: young men often continue to reside in their home regions and exhibit a preference associated with participation in traditional lifeways and activities, such as hunting and fishing. Out-migration and the pursuit of higher education increasingly characterizes the path of the young women (Hamilton and Seyfrit 1993; 1994, Huskey et al. 2004: Martin 2009, Rasmussen 2009). Other research findings have also highlighted this now commonplace female flight from northern rural regions and its gendered qualities, attributing it to changing gender roles as well as social problems in small communities (Glendinning et al. 2003; Muilu and Rusanen 2003; Bjarnason and Thorlindsson 2006; Donkersloot 2012).

Out-migration from coastal communities is also influenced by the increasing hegemony of globalized values such as those reflecting the necessity of higher education. Discourses concerning the unsuitability of fishing as a career path gain strength in northern, coastal communities and primarily in the school setting. Corbett's (2004) Digby Neck fishermen describe their experience with formal education and teachers from outside of their communities as their being almost missionized away from fishing. Increasingly in Alaska and in other northern coastal regions such as those of Nova Scotia, coastal youth narratives reveal how they often experience disillusionment, however, when their enculturated practices conflict with cultural capital requirements of the university path.

These findings indicative of the current realities for youth in northern, fisheries dependent communities are exemplified in those studies conducted in Newfoundland (Hamilton and Seyfrit 1994) and Corbett's rich ethnographic studies of Digby Neck, Nova Scotia (Corbett 2004, 2005, 2006, 2007a, 2007b). These works show how cultural capital, defined as the honors, educational qualifications, and other forms of knowledge and behavior that bestow social distinction (Froerer 2012) is, in northern coastal communities, locally acquired through place based practices; centered on practical knowledge and multiple skills valuable for a coastal livelihood and expressed through ties of kinship and other forms of social capital. The narratives of Alaska coastal youth demonstrate how these locally based forms of capital can be at odds with the formal education and specialization of skills demanded by the global economy into which youth are now increasingly drawn. Youth and parents often reported the trend for youth to attend college, but often for only a short period of time returning home far in advance of completing their degrees (Knapp and Lowe 2007). Those who do earn degrees, must sometimes leave home permanently to pursue careers unavailable at home. The literature on rural youth highlights this 
significant conflict (Byun et al. 2012) between allegiances to family and community and new expectations placed on rural youth to acquire the cultural capital they need to become global citizens. In changing the meaning of place (Giddens 1991; Massey 1995; Appadurai 1996; Putnam 2007), economic and cultural globalization processes are at odds with localized livelihood strategies and cultural affinities.

Like other northern rural youth, young people in Alaska's coastal communities could be, therefore, currently "caught between traditions that no longer work and new opportunities they are not ready to grasp" (Heggen 2000:47); a fact which highlights how different today's coastal youth choices are from those of their parents (Paulgaard 2002). These challenges are common to residents of coastal communities worldwide who experience greater competition for diminishing resources in an age of enclosure and privatization. In identifying similar problems Atlantic fishing communities were facing thirty years ago, Hanson et al. argued: "New approaches to coastal communities are urgently needed, i.e. inquiries focusing on their needs, their values, and their aspirations" (1984:240). In Alaska, new approaches to sustaining coastal communities require including youth in the integration of a strong local vision to meet the challenges presented by global economic change. The following narratives provide a coastal youth perspective on these issues.

\section{Study communities and study population demographics}

The current study included 88 youth from five Gulf of Alaska coastal communities: Sitka, Petersburg, and Craig in Southeast Alaska, and Kodiak and Ouzinkie in the Kodiak Archipelago. See map in Figure 1. Community criteria for selection included communities that fit the Magnuson-Stevens Fishery and Management Conservation Act's definition of a fishing community as "a community which is substantially dependent on or substantially engaged in the harvesting or processing of fisheries resources to meet social and economic needs and includes fishing vessel owners, operators, and crew, and United States fish processors that are based in such community". a.The communities selected both fit this definition and are archetypal in their representativeness of Alaska coastal communities with traditional commercial fishing

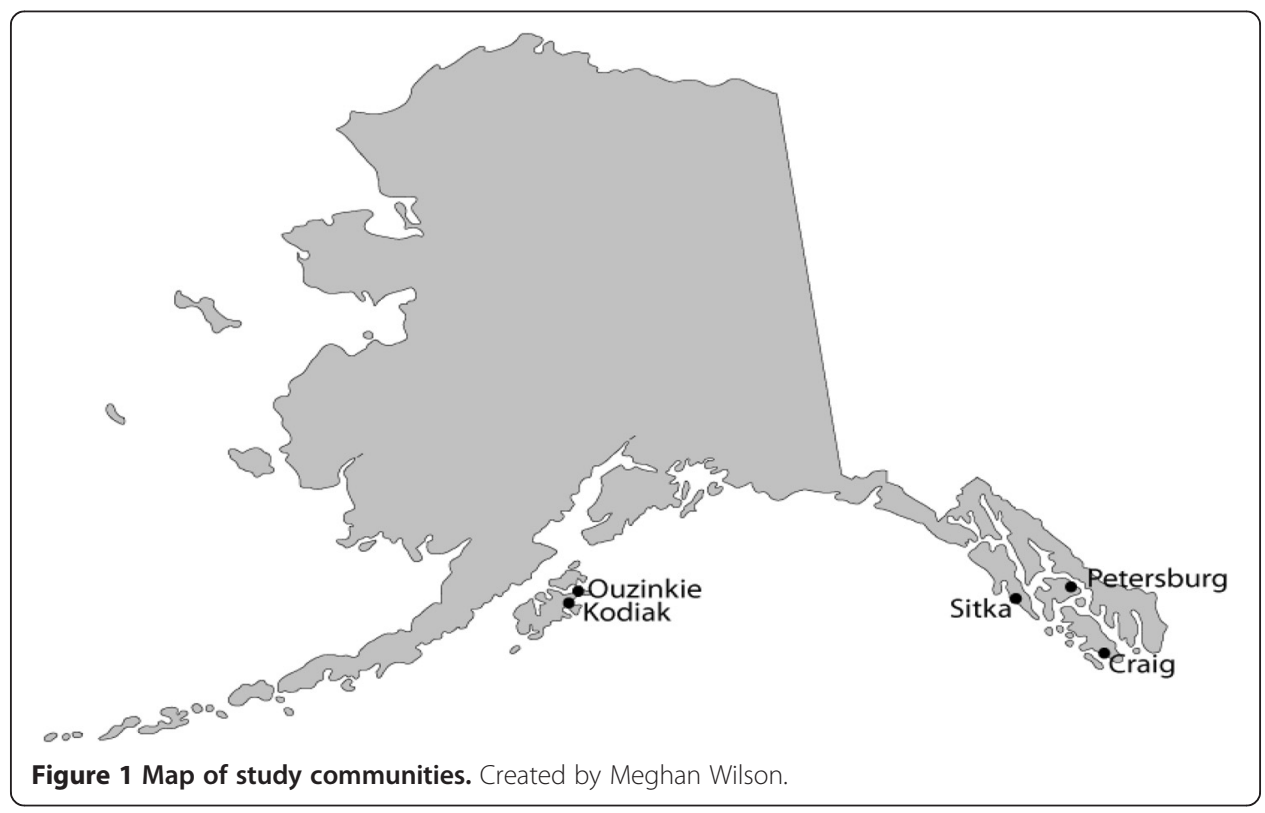


economies. Historically, each of the selected communities are currently, or have evolved from single-sector economies in which primary economic activities are fishing, fleet services, and/or fish processing. The study targeted both regional "hub"-scale communities such as Sitka and Kodiak (i.e., >1000 residents) that have more diversified economies in addition to "village" scale communities, such as Petersburg, Craig, and Ouzinkie (i.e., $<1000$ residents) with more limited economic opportunities.

Because of their remoteness and individual isolation in which few roads connecting them to other communities exist, however, Alaska coastal communities do tend to be unique and somewhat idiosyncratic in their characteristics. The communities of Sitka, Petersburg, and Craig are located in Southeast Alaska where lush rainforests dominate the coastal landscape. Sitka is a picturesque, multicultural regional hub community of fishermen and artists with a thriving tourism sector based primarily on the cruise ship industry. Petersburg is a unique colony of fishing families of primarily Norwegian descent. Craig is a commercial fishing community on Prince of Wales Island where a mixed population of non-Alaska Natives and Alaska Natives (of Tlingit and Haida descent) reside. Lying 600 miles $(966 \mathrm{~km})$ to the northwest of the Southeast communities, Kodiak and Ouzinkie are also situated within the tree line but are characterized by a more exposed coastal landscape than the protected bays and coves of Southeast Alaska's Inside Passage. Kodiak is the hub community for the Kodiak Island archipelago villages with a diverse population of Alutiiq Alaska Native residents, Coast Guard personnel and their families, non-Alaska Natives from the rest of Alaska and the United States, and a transnational fish processing worker population from countries as diverse as the Philippines and Mexico. Kodiak is primarily a commercial fishing and processing center with an industrial harbor and a multi-species fleet. Ouzinkie is a small, Alutiiq Alaska Native village located on Spruce Island, 12 miles north of the city of Kodiak.

Table 1 indicates how participants for the current study were evenly split along gender lines: 44 male participants and 44 female participants for the study population as a whole, but the sample composition varied from community to community. ${ }^{\mathrm{b}}$ Median age of participants was 17. A little more than half of participating youth reported a primary ethnicity of Euro-American and about one quarter reported an Alaska Native/Native American ethnicity. The remaining 17\% reported themselves as Multi-Ethnic, Latino, Asian, and Pacific Islander. Alaska Native respondents primarily reside in Sitka and Ouzinkie. Asian respondents were primarily of Philippine origin and reside in Kodiak.

\section{Methods}

The study's qualitative focus group methodology conducted with community youth was extended from previous research (Lowe 2008) in Alaska Peninsula and Aleutian Island communities. The former study examined socioeconomic impacts of a rationalization program in Bering Sea crab fisheries. Although the primary focus of the Bering Sea research was documenting the experience of local fishermen affected by restricted access management programs, focus groups were also conducted with teenagers in the region's coastal communities to obtain their perspective on how they envisioned their futures. The current research was conducted to extend this aspect of the Aleutian study's methodology down the coast to further explore preliminary assumptions that emerged from the former study regarding Alaska coastal youth current occupational choices and affinities, new expectations regarding higher education, and community in- and out-migration. 
Table 1 Study population demographics

\begin{tabular}{|c|c|c|c|c|c|c|}
\hline Study community & Sitka & Kodiak & Petersburg & Craig & Ouzinkie & \\
\hline Community pop & 8,627 & 6,626 & 2,973 & 1,101 & 170 & \\
\hline \multicolumn{6}{|l|}{ Study participants } & Total \\
\hline Female & 13 & 10 & 12 & 5 & 4 & 44 \\
\hline Male & 11 & 14 & 4 & 12 & 3 & 44 \\
\hline Total & 24 & 24 & 16 & 17 & 7 & 88 \\
\hline \multicolumn{6}{|l|}{ Ethnicity } & Total \\
\hline Euro-American & 14 & 15 & 13 & 9 & & 51 \\
\hline Alaska native/Native Amer & 8 & 1 & 2 & 5 & 7 & 23 \\
\hline Multi-ethnic & & 2 & & 2 & & 4 \\
\hline Latino & 2 & 1 & & 1 & & 4 \\
\hline Asian & & 4 & & & & 4 \\
\hline Pacific Islander & & 1 & & & & 1 \\
\hline Unknown & & & 1 & & & 1 \\
\hline Total & 24 & 24 & 16 & 17 & 7 & 88 \\
\hline \multicolumn{6}{|l|}{ Place of birth } & Total \\
\hline Alaska & 19 & 15 & 6 & 9 & 7 & 56 \\
\hline Washington & 1 & 1 & 8 & 4 & & 14 \\
\hline Oregon & 1 & 2 & 1 & 2 & & 6 \\
\hline \multicolumn{2}{|l|}{ Other Western U.S. States } & 1 & & 1 & & 2 \\
\hline U.S. Midwest & 1 & & 1 & & & 2 \\
\hline U.S. East & & 2 & & & & 2 \\
\hline U.S. South & 1 & & & 1 & & 2 \\
\hline Outside U.S. & & 3 & & & & 3 \\
\hline Unknown & 1 & & & & & 1 \\
\hline Total & 24 & 24 & 16 & 17 & 7 & 88 \\
\hline
\end{tabular}

Source: Focus Group Questionnaire.

A structured focus group interview protocol of 30 questions was administered between 2008-2011 with groups of high school students and groups of 18-24 year old youth. See Additional file 1 for interview questions. Focus group interview questions were designed to help youth describe their lifestyle today and how they view future opportunities in work, education, or training. In the author's current research among Alaska's youth, the focus group approach has proved to be an effective way to access some initial dimensions of local youth culture. (Ervin 2005) notes how for applied anthropologists, the method affords them flexibility in the absence of funding or time for full scale ethnography and that it additionally produces a substantial amount of information (2005:175). Participants included secondary-level students (age 16-18) and post-secondary level (age 18-24) informants. Secondary level students were stratified into two groups, "junior" or third year secondary level students and "senior" or fourth year secondary level students. Secondary-level students were recruited through community schools. Post-secondary level informants were recruited through high school guidance counselor offices, announcements posted in the community, and by convenience samples. All minors (under the age of 18) included had a consent form signed by their parents allowing children to participate. Participants over the age of 18 signed assent forms. The focus group methodology usually limits group size to 8-12 participants (Krueger 1988) and youth were selected by a random draw of permission 
forms to fill three group interviews conducted in each of the five communities. Focus group interviews were recorded with a digital recorder. They were transcribed and subjected to content analysis using Atlas ti qualitative data analysis software. Codes were derived from the topic of each of the interview questions: i.e. positive and negative attributes associated with community life, academic opportunities and constraints, leisure pursuits, aspirations for the future and particularly occupational goals, and community in- and out-migration. Descriptive statistical functions in SPSS were used to analyze questionnaire data and the occupational ranking data collected. Participants were administered a brief questionnaire of 9 questions attending to age, gender, ethnicity, education level, residence patterns, and parent occupation. They were also asked to rank a list of 20 occupations in order from most appealing to least appealing.

\section{"Close-Knit" Communities}

When asked to describe unique qualities of their communities during the group interviews, Alaska coastal youth first overwhelmingly commented on and agreed about the close interconnectedness between residents of their home communities and an associated collective connection to the place of those communities. In many instances, youth described their communities as "close-knit" and how this particular attribute distinguishes their communities from others. Describing social relations as "close-knit" signifies the traditional social capital shared between community members based on strong social ties and networks extending from the family, place-based attachments, and various forms of social control.

I think Sitka is a lot more socially close-knit than anywhere else in the state.

-Sitka High School Senior

Well, we're all kind of close-knit, that's a good thing, I guess.

-Ouzinkie High School Senior

Plus that we're so close-knit that when someone dies, there's a huge connection-we all get together...so that's good.

-Petersburg High School Senior

The interesting thing about Craig is that is a close-knit community, considering the diversity of people. Everyone knows everyone. Everyone knows me.

-Craig 18-24 year old

In their extensive study among rural youth in Scotland, Glendinning et al. (2003) describe this sentiment as common to today's northern rural youth, once again tied to the attachment to family and other locally based social relations, the community's natural environment, and feelings of safety associated with the home area. Scottish youth also used the exact phrase "close-knit" to describe the social cohesiveness characteristic of their communities as did Skaptadóttir's (1996) female informants of remote Icelandic fishing communities.

The deep social ties participants described in the group interviews are first grounded in enculturation experiences centered in extended family structures and multiple generations, coalescing around a coastal and commercial fishing lifestyle. Coastal youth understand the isolation of their communities is what draws them together and the common upbringing 
during their childhood. In most of the communities, respondents remarked on the feelings of safety they experience at home among family members and other community residents. Family is also the conduit through which coastal youth experience and learn to appreciate the beauty of their natural environment by participating in outdoor activities in the course of family life and their childhood, eventually extending to outings with friends. For all the respondents but chiefly the youngest, the very important local outdoor activities such as subsistence fishing and hunting were conducted among family members over others.

It just kind of seems like a family activity. Everybody gets on the boat or goes to the dock or whatever you do, and you grab the fishing poles and sit there and cast and you just kind of sit there and listen to old music.

-Sitka High School Senior

Participants also described the beauty of their physical environment as another positive community attribute and as essential to their own feelings about home. Many of these activities were described as fondly experienced within the family first, particularly those associated with subsistence fishing and hunting. They described a wide range of these activities that include both subsistence ${ }^{\mathrm{c}}$ and recreational pursuits.

The thing about Sitka I like is that it is on an island. So you would think that there isn't that much to do here, but the amount of things you can do outside-whether it is subsistence fishing or hunting-the opportunities are just overwhelming. You could spend a lifetime and not get everything done here.

-Sitka High School Senior

Youth were asked if they saw themselves raising their own families in their home communities in the future. The response was positive in all the study communities, particularly for the early years of a child's life in which they engaged in these family activities, and which they themselves treasured as a central element to their own identities. Alaska coastal youth interviewed for this study expressed ambivalence about whether or not rural communities are necessarily good places for adolescents to live, however. Once Alaska focus group participants' imagined future children reaching their own current ages, there was more indecision among them about whether or not remaining in the home communities would be beneficial to their children. They described forces of social control as another defining aspect of the close-knit nature of their communities; that gossip in particular was a powerful weapon in constraining their behavior and shaping their self-esteem. In all the Alaska study communities, youth commented on the dangers of earning a reputation for a careless or stupid act; a reputation that would forever be associated with one's name.

Participants' indecision about the benefits of coastal community life for adolescents was also influenced by a concern about boredom and bad weather linked to drug and alcohol abuse for some and by a lack of access to wider opportunities for others. Respondents fully recognized the advantages and disadvantages of the isolation of their home communities.

I think it was a good place to grow up because I basically lived in the outdoors, but, I mean, the wintertimes, you know, for the kids now there's temptation for alcohol and drug abuse here because there's nothing to do in the wintertime.

-Kodiak 18 to 24 year old 
The ambivalent feelings participants had about both the advantages and disadvantages of living in a small coastal community were eventually framed within a discussion of whether or not young people would pursue traditional and local occupations or broaden their opportunities by pursuing higher education outside of these communities. Most of the study participants were facing and living important life decisions at the time of these interviews which they also approached with some ambivalence, i.e. their occupational and educational paths, and whether or not they would leave or stay in their home communities. Their narratives revealed this tension between expressed cultural affinities for small town living and self-directed, hands-on work and the equally strong desire for the enticements of getting a college education, perhaps leaving the community and re-settling elsewhere, and experiencing a life perceived as more cosmopolitan.

\section{"Hands-On" People}

The practical knowledge and multiple skills Alaska coastal residents require for survival in a harsh environment with limited economic opportunities emerged in discussions of employment preferences for study participants. Alaska coastal youth collectively expressed a preference for physical or self-directed employment, often noting their affinities for "hands-on" work now and in the future.

\section{"Gotta work with your hands more"}

I would want to be one of them [Mechanic/Welder or Construction Worker] because they're somewhat high paying and it's a hands-on job and something that you could maybe make something for yourself, or fix your own car or something.

-Ouzinkie High School Senior

But if I were to really pick something that I'm passionate about, probably a teacher. Something that's more hands-on.

-Sitka 18 to 24 year old

What they allow us to do in culinary arts class is pretty cool, you get hands-on.

-Kodiak High School Senior

Participants were asked to rank a list of 20 occupations available to them in their communities; an activity that was followed by a group discussion about those rankings. Study participants expressed this "hands-on" orientation and an affinity for self-directed and vocational work over "white collar" or professional occupations. In analysis, the data were stratified by the group as a whole, by community, by gender, by ethnicity, and by sub-region. For the group as a whole, findings demonstrate a cultural affinity toward "hands-on", self-directed and vocational work such as air piloting ${ }^{\mathrm{d}}$, being a small business owner, culinary arts, and skilled trades over more office bound occupations. Table 2 shows the average ranking for each occupation. The answer choice with the largest average ranking is the most preferred choice for the group as a whole, for the male participants, and for the female participants. ${ }^{\mathrm{e}}$ 
Table 2 Weighted average occupational ranking, all, women, men

\begin{tabular}{llllll}
\hline Occupation & All respondents & Occupation & Men & Occupation & Women \\
\hline Pilot & 14 & Pilot & 16 & Health care & 15 \\
Small business owner & 14 & Mechnic/Welder & 14 & Small business owner & 15 \\
Chef/Cook & 13 & Construction & 14 & Chef/Cook & 14 \\
Teacher & 13 & Small business owner & 13 & Artist & 14 \\
Health care & 13 & Fisherman & 13 & Teacher & 14 \\
Mechanic/Welder & 12 & Chef/Cook & 12 & Pilot & 13 \\
Artist & 12 & Computer programmer & 12 & Biologist & 11 \\
Construction & 12 & Guide & 12 & Computer programmer & 11 \\
Computer programmer & 11 & Charter boat operator & 12 & Office worker & 10 \\
Fisherman & 11 & Teacher & 11 & Guide & 10 \\
Guide & 11 & Biologist & 11 & Mechanic/Welder & 10 \\
Biologist & 11 & Harbormaster & 10 & Hairdresser & 10 \\
Charter boat operator & 10 & Health care & 10 & Fisherman & 10 \\
Harbormaster & 9 & Longshoreman & 10 & Construction & 9 \\
Mayor & 9 & Mayor & 10 & Charter boat operator & 8 \\
Office worker & 9 & Artist & 9 & Mayor & 8 \\
Longshoreman & 8 & Fish processor & 7 & Harbormaster & 7 \\
Hairdresser & 7 & Office worker & 7 & Post office clerk & 7 \\
Post office clerk & 6 & Post office clerk & 6 & Longshoreman & 6 \\
Fish processor & 6 & Hairdresser & Fish processor & 5 \\
\hline & & & & \\
\hline
\end{tabular}

\section{"I don't like the idea of sitting at a desk all day".}

Occupations with lower ranks were associated with a lack of personal power or tedious and/or associated with outsiders and their values, including: office work, fish processing and tourism related jobs. Coastal youth do not see themselves working in occupations in which they are required to sit at a desk in an office as they describe themselves as active, outdoorsy, and again, "hands-on".

I like to be outdoors, I don't really want to be in an office.

-Ouzinkie 18 to 24 year old

I just don't want something that's boring. I want something that's new and interesting.

I don't know, I just see myself sitting in a cubicle or something and that's so

unappealing to me. I want to be in charge of my days beyond an office.

-Sitka 18 to 24 year old

As my worst, I picked office worker because I can't stand being stuck inside. That would drive me AWOL.

-Kodiak 18 to 24 year old

More monotony in those jobs...I am not a fan of just sitting at a desk.

-Craig 18 to 24 year old

I don't think it would be fun to sit in a cubicle all day.

-Petersburg High School Senior 
Because it's kind of like at school, you're always sitting down, so, I mean, when you're fishing or something you're using your hands.

-Kodiak High School Junior

Entry level opportunities in traditional, hands-on occupations in many coastal communities such as fishing are diminishing, however, and expectations for young people in rural Alaska to pursue higher education are increasing. The preferences expressed in the quotations above are necessarily at odds with increasing expectations for coastal youth to attend college where the focus is on training for professional, and arguably desk bound occupations. Corbett describes this new cultural expectation for youth to eventually leave their communities manifesting as a "migration imperative" for his informants in Nova Scotia; how "formal education and leaving the community of origin, or 'getting out' was understood as an ethical and even moral responsibility" (Corbett 2007a:431).

Alaska focus group discussions did demonstrate how going to college has now become a logical life path for Alaska youth despite some underlying questions about the actual practical utility of a college education. Coastal youth feel pressure to go to college from parents, friends' parents, and teachers. In many cases, study participants will be first generation college students in their families although some participants' parents had attended college but had not finished. Few parents of interviewed youth had college degrees; a fact which highlights how different today's coastal youth choices are from those of their parents:

Neither of my parents went to college so they really want me to go but there isn't like a decided thing that I should do, it's really up to me. But they want me to go, they want to help me as much as they can.

-Petersburg High School Senior

A lot of pressure to go to college, just because my family struggles so much with money and it seems, like, all the time, we're trying to find another way to get more for this or that. So, I get a lot of pressure to go to college and be able to get a really good job and, you know, be really stable, and just do better is basically a roundabout way of saying it - it's just to do better.

-Sitka High School Junior

My dad has been working labor intensive jobs since he was very young... and he wants to make sure that I don't do the same thing with my life. He wants me to go to college or get some sort of white collar job. So I won't be throwing out my back at age 30 like he did. -Sitka High School Seniors

Focus group discussions demonstrate how coastal youth are encouraged by their elders to pursue a path towards "useful", "promising", or stable, high paying careers such as in engineering and health care- whether or not the young person has an interest in or adequate academic preparation for those fields. One high school junior explained how he was interested in pursuing an engineering degree in the future and how he had already selected an engineering school a relative was attending outside Alaska. Later in the interview, however, we discovered this particular student did not like math nor did he like working with computers. Although he was focused on engineering as a career path, he seemed to be unclear about what engineers do. Overall, this youth's narrative was reflective of a shared, vague 
perception of the future among Alaska coastal youth interviewed for this study and in some cases, inadequate guidance in understanding options for post-secondary education or training for what are now numerous first generation college students. Participants discussed how adults encouraged them toward "useful" paths of study or "promising fields":

When I graduated, nursing was huge. I am going to school for nursing right now and everyone constantly tells you that it's a great field to go into. Whereas I have a friend going into interior design and here, people are like, interior design, what are you going to do with that? There are so many houses here in town. But I can't see that person coming back here to live because of the choice that they make. That person is going to have to go down south and find something to do.

-Petersburg 18 to 24 year old

-The only person in my family that went to college was my mom. So they are kind of like, if you are going to go to college or get a job, make sure it is in something useful. So nothing like art, which I am really into. So they want me to do something like become a nurse, but all of my friends want me to do art. So there is that kind of pressure.

-My parents just want me to do something that is useful. They want it to be their money's worth with college.

-Yeah, neither of my parents went to college and my dad thinks it is a really stupid idea, so they are kind of like if you go to college you better make it useful.

-Sitka High School Seniors

\section{"Girls usually go off to college. Guys stay here and fish or do other things".}

Any exodus out of rural Alaska communities towards higher education is being definitively led by the young women of those communities, reflecting both a growing national gender gap in higher education and a pronounced trend in Alaska (Kleinfeld and Andrews 2006). In the Alaska occupation ranking exercise (see Table 2), there were gendered differences in responses when young men awarded higher ranks to occupations such as fishing and mechanics and when they were vociferous in their opinions about the inherent value of these occupations. Within the group discussion, the opinions of young women were overshadowed by those of their male peers who particularly mocked any discussion pertaining to what was conceived of as more feminine occupations such as hairdressing (though technically a "hands-on" occupation), demonstrating the well-documented "macho complex" (Orbach 1977) characteristic of men in fishing societies. Women privately ranked occupations in art trades or in health care and teaching higher. Some of the young women did note that hairdressing is a viable way to make a living for women in fishing communities and more congruent with family life than either fishing or fish processing. The Alaska focus group discussions also reinforced possible reasons for increased female flight from Alaska's rural communities, i.e. strong gender stratification and traditionally defined gender roles limiting employment opportunities for women at home (Corbett 
2007a); constraints perhaps unacceptable to some of today's young women who understand there are other options for them outside of their rural communities.

-More girls go to college, a lot of guys drop out of high school.

-I think a lot of guys see the fishing business as very profitable and you don't need any kind of education with that. A lot of guys hop on a fishing boat in the summer rather than get ready for college, versus girls.

-Sitka High School Seniors

A lot of the girls in our classes did go to school and they did do at least something they have got some sort of degree. Whether they will use it or not because they came back-probably not. But the boys, they go to school and they all come back.

-Petersburg 18 to 24 year old

I don't know what the population is, but I am guessing that there are a lot more males my age then females my age. It is just not a place where females want to be. They don't come here for any reason. And then one thing I see is if you are a single guy, your choices are girls with kids. There are a lot of females my age, but they have problems, like drinking problems or drug problems and for a single guy who is looking for a girlfriend it is not a good place to look.

-Craig 18 to 24 year old

\section{Outsiders in Alaska coastal communities}

Paradoxically, whereas factors indicative of the globalization of fishing and processing industries are influencing out-migration of youth and particularly, young women, globalization processes also result in increasing in-migration of outsiders to coastal Alaska communities, particularly in association with the expansion of the processing and tourism industries. Study participants were quite clear in their general disdain for the occupation of fish processing because of first, the low pay and poor working conditions, but also primarily because they now associate this work with transnational labor and foreigners in their communities. Fish processing has never been particularly culturally congruent with local Alaska lifeways and has been dominated by outside entities from the industry's beginnings in the state. The current aversion to processing work is, however, a reflection of what is now a generation of changes in the industry. Local fishing families used to work in the processing plants in Alaska and many other northern places-particularly women and young people. However, this participation has changed as northern fisheries became more globalized in the 1970s with the establishment of Exclusive Economic Zones (EEZs). In Alaska, a gradual "Americanization" of Alaska's fisheries was achieved through the 1980s, when foreign fishing companies were moved out of fishing activities within the U.S. EEZ, but as fish processors were allowed considerable U.S. shoreside investment in processing operations and the ability to bring in their own labor force (Lowe 2008).

No. 24: Yeah, there are a lot of foreigners.

No. 22: I think it's because they have different work standards and they can get away with a lot of stuff. 
No. 21: Yeah, they can work them longer for longer hours, cheaper, and without paying them overtime.

-Sitka 18 to 24 year olds

"I think being a guide is my last choice, because I hate the tourists here, and I have bad thoughts about that".

Tourism is another coastal industry expanding in many of Alaska's coastal communities and is a means for communities to diversify their economies. It is, however, an industry locals also associate with outsiders present in the community. Despite grudgingly admitting tourism brings in much needed local revenue, youth interviewed for this study dread a tourism-based future. In general, they dislike the disruption of tourist crowds in the summer and are reluctant to share the uniqueness of their home communities with strangers industry brings in who know very little about Alaska or coastal community residents' way of life. In the group discussions, youth were particularly unfriendly towards the sport fishing industry whose operators are generally headquartered in places outside of Alaska and who are not considered locals contributing to the viability of Alaska communities. At the time of this research, commercial and charter fishermen in Southeast Alaska were waging an intense battle over allocation rights to dwindling halibut stocks.

Well, charter boats get a really, really bad name in Sitka because almost all of the charter boat operators come in from out of town and then, you know, do their thing, then leave again and take the fish.

-Sitka High School Junior

They are important and everything, but I don't necessarily like them. Most of the charters are for tourists. Most of the charter boat operators are what I would sort of consider a tourist because they are only here during a couple summer months.

-Craig 18 to 24 year old

\section{Alaska coastal communities and the "real world"}

Although Alaska coastal youth are ambivalent about the presence of outsiders in their communities, they were enthusiastic about traveling to other places themselves. Across the study communities, youth commented on how they perceived their isolated communities as distinct from the "real world." Despite their recognition of being isolated, their interviews also demonstrated they are very much aspiring global citizens, connected to what they do perceive as the "real world" through media and traveling for school functions and during vacations.

I am really excited to leave and go out to the real world. But, when you are gone for at least two weeks you get this feeling of wanting to come home. It is your home. It is weird how you can be attracted to such a small place.

-Petersburg High School Senior

This will always be home, regardless of where I go, this will always be my home. But it would be nice to get out for a while and try experiencing living life for a couple of 
years in the real world and then probably I'll eventually miss this place and want to come back. But I don't know, as long as I visit here, frequently and often, I can probably stand being away from it and living somewhere else.

-Sitka 18 to 24 year old

Interviewer: Would you say that this town was a good town to grow up in?

Number 82: Kind of. You get to know everyone, but I think that if you grew up in a big city, you would have more of an idea of what the rest of the Lower 48 is like.

Number 81: It is really protected here.

Number 86: It is almost not the real world to a point.

-Craig High School Juniors

Study participants worry about the disadvantages of living in a remote community, and particularly about their academic preparation as they are now faced with new expectations to attend college. The most noteworthy negative school experience for coastal youth was the lack of diversity and rigor in course offerings at the secondary level. The majority of Alaska rural schools, including several of those the study participants attend, are overwhelmingly plagued with teacher turnover or lack of resources to cover all the subjects students need at once. Students themselves are painfully aware of these issues and express concern about how a school's lack of offerings might affect them in the future and particularly in lives that might be lived outside of their communities. Improving or standardizing the curriculum in the state's schools, and particularly in math and science, is a pressing issue for Alaska coastal youth:

There's not many options. There's some classes that they call Independent Studies... I'm in a class that a teacher can't even really help with...there's a math class and there's no one person that actually specializes in math.

-Ouzinkie High School Senior

One of the bad things about the school is that the electives are really limited to what the teachers can do. And a lot of the time what happens is that teachers move up here and discover that they don't like it and move again.

-Craig High School Juniors

We need a different math program. Get us on the same math program that all the other schools around the country are on so we could get into college easily.

-Sitka High School Junior

Formal education becomes an important locus for accessing the world outside of the community. Connection to the "real world" is also achieved through travel with family and travel for sports or other school activities. School related travel provides Alaska coastal youth with opportunities to meet with friends outside their communities and to thereby establish and reinforce connections with other Alaska communities. They also depend on the connections to the "real world" the Internet affords them for shopping, social networking, and taking online courses despite their complaints of internet service being too slow in many communities. Alaska coastal youth want to keep up on the 
fashions, movies, and electronics crazes, go out to eat in restaurants and drink fancy coffee, and they'd like to have access to services that are "open 24/7" which seemed to be the ultimate mark of modernity. They want to be able to participate in a wide range of sports, arts, and other activities.

\section{"I don't think people realize that they love it here until they are out of here for a while."}

Youth were asked about their residence plans for the future. Study participants themselves were unclear about their future place of residence or career path, but do know that they need to experience the world outside their home communities. There is a recognition among many of the study participants, particularly among the older, 18 to 24 year olds, that there is no substitute for home and the connections they have to it. Not all participants, therefore, were completely definitive in their plans to move away permanently but rather expressed how they merely needed to try something different for a period of time. They have seen older siblings and peers have those experiences they desire in college or elsewhere, only to return home to coastal Alaska; or conversely, educate themselves out of a job at home preventing them from returning.

Most of the high school students interviewed had plans to leave their home communities, at least in the short term for college. Similar to youth in many places, Alaska coastal youth demonstrate a restlessness and desire for new experiences away from home and look forward to these experiences after high school that now almost always include college or some kind of post-secondary training-even if they don't actually end up going or if they eventually return within the first year.

My sister went to college last year and she was really excited to live in Seattle, because we weren't really familiar with the big city and she really liked it at first, but then she started missing it here, just the love and comfort from all of your friends and everyone that knows you. And, not much happens here. There was kind of a lot of crime in Seattle.

-Petersburg High School Junior

My sister (she's thirty) and my brother in law, they have two kids and they don't like it down south as much and they want to move up here 'cause it's a better environment for raising kids...And you know up here, everyone's nice so they want to move up here but my brother in law can't get a job here...He's an engineer. And my sister had a major in architecture and design.

-Petersburg High School Senior

Number 24: It's almost like it's like a fantasy what it's going to be like on the other side, the grass is going to be greener. But you get down there and you don't realize that you're going to be homesick.

Number. 21: Yeah, you miss this place once you get out. I mean, I have travelled and have been gone for months at a time and I really do miss this small town. Number 22: Well, sometimes living here all your life doesn't really prepare you for what it's really going to be like when you're nobody in some big place. 
Number 21: Yeah, nobody knows you.

-Sitka 18 to 24 year olds

\section{"No, I don't like fishing".}

Alaska youth narratives ultimately demonstrate social change occurring in Alaska coastal communities as a result of globalization processes: the globalization of the fishing industry, changing gender roles, new cultural pressures for youth to acquire higher education, as well as youth desires for new experiences outside their home communities. The gradual move away from inshore, artisanal fishing towards offshore, industrialized and factory production operations in which local fishermen have less of a stake has contributed to the perception of fishing an unattractive vocation for northern, coastal youth (Arbo and Hersoug 1997). Although Alaska youth may afford respect to traditional local vocations such as fishing in the way many coastal residents identify as or with fishermen and their lifestyle (Reedy-Maschner 2010) they might not see themselves pursuing this line of work in the future in the face of numerous barriers to entry in fishing industry occupations and because of hegemonic discourses promoting higher education and disparaging local livelihood strategies. Ambivalence towards fishing as a vocation was a particularly prevalent sentiment among the high school participants whereas the 18-24 year old participants interviewed were either fishermen themselves or still connected to fishing in some way through family and other social relations. In most of the communities, younger participants described how youth would get "stuck" in the fishing lifestyle in which opportunities for advancement were currently minimal considering the barriers to entry for youth, i.e. high cost of quota share.

For the majority of young people interviewed for this study, a career in fishing does seem unlikely. Study participants often spoke about grandfathers who owned the boats and the quota and for whom they'd worked as deckhands exposing these generational changes occurring in the industry and in communities. This social change is often colloquially referred to as the "graying of the fleet" in Alaska (Rosvold 2007; Loring and Harrison 2013). Study participants spoke of fishing in the summer and as a means to make pocket money rather than as a future vocation. Some younger coastal youth also confessed to disliking commercial fishing work.

I fished for a year, I didn't really like it. I was a fisherman. I just don't like being that dirty or anything like that.

-Ouzinkie High School Senior

I have just always been fishing since I was a little kid and I have never really liked commercial fishing all that much. I am always on the boat and it has never been something that has interested me.

-Craig High School Junior

Yeah, I don't want to work on a boat as much. I don't like fishing as much as everybody else does but I mean, I could live with it but it's not something I really wanna do at all. 
Interviewer: And Number 84, you don't want to be a fisherman either?

No. I don't like fishing.

Interviewer: Is your family involved in that?

Just my grandpa.

-Craig High School Senior

\section{Discussion and policy recommendations}

The findings of this study provide an attempt to understand social change in Alaska's rural and coastal communities and address the challenges the next generation their residents face in a globalizing world. Understanding the dynamics of the lived experience of youth is at the heart of understanding how Alaska's rural communities with cope with socioeconomic change and what type of policy recommendations can be made to address current and future challenges communities face in planning for and maintaining their long term viability. Process policy recommendations include giving youth a voice in discussions of problems or challenges and empowering them to not only help find the solutions but to act on them. One of the focus group exercises was for youth to imagine themselves a city council or school board member and to think of ways they would solve community problems. Just providing them with this context for decision making roles invigorated the discussion and helped participants focus on the most pressing issues. The content of the policy recommendations emerging from this study, therefore, come from coastal youth themselves.

They include: 1) investing in training coastal youth for culturally relevant and desirable work, 2) recognizing youth might want to return to their home communities in the future, particularly with their families, 3) giving youth a voice in community affairs and policymaking to cultivate future community leaders and stewards, and 4) committing to economic development strategies that encourage local ownership in coastal resources and industries.

\section{Culturally relevant training and work}

Hanson et al. (1984) identified two vitally important mechanisms for maintaining coastal community viability: 1) fostering occupational pluralism and 2) balancing in- and outmigration. In the context of increasing restructuring of fisheries, relying on a single sector economy puts today's coastal community in a vulnerable position. Even high school aged students in Alaska's coastal communities understand the consequences of doing so and are asking for better preparation to meet future challenges. The dilemma they particularly face is a lack of interest and cultural affinity towards potential growth industries for their communities, such as in fish processing and in tourism.

Corbett (2005) makes a call for "place based education and contextually specific curriculum" as a means for mitigating the conflicts northern, coastal youth face and stemming brain drain. Their apparent preference towards vocational work that is skill-based and "hands-on" does position Alaska coastal youth well in developing their communities' service sectors. In addition, they demonstrate themselves to be amenable towards self-directed work, such as in the case of small business owners. However, their cultural orientation towards work comes into conflict with limited academic course offerings at the secondary level combined with increasing cultural pressure to obtain a college degree which arguably prepares them less in skill based and service trades and more for 
the professional, desk and office bound work they have an aversion towards. For their educational needs, they are insecure about their academic abilities, particularly in mathematics and called for a review of the current math curricula used in rural schools and the standardization of that curricula with other programs outside Alaska. They also want a greater diversity in their choice of electives which might either provide them with the means to securing employment in their home communities, i.e. in vocational trades or in pursuing career paths outside of Alaska, i.e. with foreign language ability. This focused guidance should originate from perhaps externally trained, but long term community residents themselves rather than school personnel who may only be temporary or short term residents in remote communities.

The phenomenon of higher levels of young, coastal women attending higher education institutions positions them well for increasing public sector and administrative work in the north (Corbett 2007a; Rasmussen 2011). Considering attrition rates for college attendance, however, the decision to go to college should be carefully considered and planned at a time of rising student loan debt and a global youth unemployment crisis. Looker and Dwyer (1998) critique the "single pathway of university study" (1998: 6) that many students experience at the secondary level. They recommend more flexibility in approaches to schooling that strengthen alternate training to the university path; and potentially those that might help youth remain in their home communities.

\section{Return migration}

Many of Alaska's coastal communities face brain drain problems because their youth are increasingly pulled towards amenities they feel "the real world" can offer. There is evidence that a gradual rural to urban migration in Alaska has begun over the past decade (Huskey et al. 2004, Martin et al. 2008; Howe 2009; Huskey 2009; Windisch-Cole 2009; Lowe 2010) but these Alaska internal migration studies do indicate that a considerable amount of this movement could be considered circular in nature and that many Alaskans lead a dual existence; one in rural Alaska and one in urban areas, as a strategy to address economic pressures but also one that sustains important ties to family, culture, and sense of place. Jentoft (1993) and Corbett (2007b) note outmigration from fishing communities tends to be variable, especially when cost of living, cost of higher education, and availability of jobs and housing elsewhere is taken into consideration. Globalizing discourses pulling youth away from localities should be deconstructed and examined for acculturating elements and potentially hollow promises. In a similar context, Paulgaard notes: "the assertion that young people must leave northern Norway in order to become modern may be seen to be based on myths rather than current realities" (2002:103). And in writing about remote communities in Greenland, Rygaard (2003) concurs that having features of the desirable urban life in rural places is in fact, achievable. For Alaska coastal youth, faster internet service and regular travel experiences would help in this regard.

\section{Giving youth a voice in policymaking to cultivate future leaders and stewards}

As today's youth are the future resilience of rural and coastal communities (Ommer 2007), logic dictates a need for their voice in today's local policy discussions (Pretty et al. 2006). Jentsch calls for the inclusion of youth in local policymaking forums and describes this process as, "youth mainstreaming". She notes: 
Promoting and supporting youth participation in rural development by mainstreaming their needs and rights could be one way of contributing substantially to the sustainability of communities. Youth's sense of ownership over, and perhaps identity with, their communities may grow (Jentsch 2006:237).

Study participants were pragmatic in their observations about the needs of coastal youth and across the study communities, earnestly discussed solutions to some of their communities' problems. The primary solution was a call for communities to invest in youth centers and activities to keep young people away from the lure of drugs and alcohol. They called attention to a lack of housing for young people starting out in life and think other infrastructure improvements such as better roads and updated schools would improve the quality of local life. Finally, they were fully aware of the limitations of their undiversified economies. They admit communities need to consider how to develop other sources of revenue outside of the fishing industry although they themselves are ambivalent about leading this charge.

\section{Economic Development Strategies}

Lying at the center of policy prescriptions for helping rural youth, McGrath (2001) emphasizes increased control over what Giddens $(1981,1984)$ refers to as "authoritative resources" which for youth in rural communities include: employment, housing, and education. McGrath also stresses how the control over authoritative resources must be endogenous, i.e. locally-controlled and locally owned. Whether coastal community residents have the ability to control their own fate in the context of globalization of coastal industries is an issue outside the scope of this study, but the study does demonstrate how from a young age, Alaska youth are proud, insular people who have difficulties with politically powerful outsiders controlling their home communities' economies. The study's participants offer several astute examples of this problem their communities experience from the non-local fishermen controlling local quota, to the transnational processing companies employing migrant labor, to the charter sport fishing operators whom local youth consider little more than glorified tourists themselves. Many of Alaska's fishing communities have been self-organizing and working on strengthening their control over access rights in fisheries and in local economic development. They face considerable challenges for maintaining this control, however, and the inclusion of youth in these processes can only be vital to their future success.

\section{Conclusion}

Alaska coastal communities are currently experiencing a high degree of economic uncertainty associated with the globalization and restructuring of fisheries, changing environmental conditions, and rapid internal and externally influenced sociocultural changes. Key discourses emerge in interviews conducted with Gulf of Alaska coastal community youth contextualizing their current position as both community members and global citizens. Alaska coastal youth see their communities as "close-knit", they see themselves having an affinity for "hands-on" work, and that somewhere outside their home communities is a "real world" they have yet to experience. Youth narratives therefore reveal a tension between local practices and imagined globalized futures. If coastal youth themselves had the power to direct policy for their future development, 
they would make their communities and state invest in them in the form of healthy activities during their youth, in providing adequate and equal access to educational opportunities, and guidance in choosing a life path that attends to their cultural affinities and cultural realities. Possessing the necessary local social capital along with life-long commitment and investment in their "close-knit", place-based communities, can enable youth to assume leadership, citizenship, and stewardship roles in the future. Policymakers could support the constructive ways the connectedness in these communities happens. When asked what youth would do to improve their communities, they overwhelmingly wanted youth or recreational centers where they had a safe and enjoyable place to exercise those connections. Educational offerings and preparation for youth should be broad enough to provide cultural capital access to opportunities that might help youth realize goals outside of their communities, but should also be culturally connected to the locality if youth decide to stay. In other words, schools and curricula could be sensitive and supportive of a "hands-on" or vocational orientation as well. Considerable focus should be placed on understanding changing gender roles, aspirations of young women in coastal communities, and attendant changing social relations and structure. A statewide discussion on the efficacy of current post-secondary education opportunities for rural youth needs continuing attention. Increased career and educational counseling is also an area youth themselves see as an improvement for their lives. Finally, today's youth do require access to the global community, which in practical terms could be articulated in faster internet service and in sustaining travel or study abroad opportunities for youth so they are able to better compare their communities with what they imagine to be the "the real world".

\section{Endnotes}

${ }^{\mathrm{a}} 16$ U.S.C S 1802 (16).

${ }^{b}$ More young women (12) than young men (4) were interviewed in Petersburg. More young men (12) than young women (5) were interviewed in Craig.

c"The customary and traditional uses by rural Alaska residents of wild, renewable resources for direct personal or family consumption as food, shelter, fuel, clothing, tools or transportation; for the making and selling of handicraft articles out of nonedible byproducts of fish and wildlife resources taken for personal or family consumption; and for the customary trade, barter or sharing for personal or family consumption" (Alaska National Interest Land Claims Act, Section 803).

${ }^{\mathrm{d}}$ Adolescents surveyed in Greenland about employment preferences or a "dream job" also listed "pilot" as a highly desirable occupation (Rygaard 2003) in the same way Alaska coastal youth did in the current study. Rygaard surmises the Greenlandic youth preference originates in air travel often being the only means of visiting places outside of remote, Northern communities as well as the airplane's symbolic power in representing the connection to these distant places and consumer goods coming from them.

${ }^{\mathrm{e}}$ Calculation of average ranking:

$w=$ weight of ranked position

$x=$ response count for occupation choice 
$\mathrm{x} 1 \mathrm{w} 1+\mathrm{x} 2 \mathrm{w} 2+\mathrm{x} 3 \mathrm{w} 3 \ldots \mathrm{xnwn}$

Total

Weights were applied in reverse, i.e. the participants' most preferred choice (ranked as \#1) had the largest weight (=20) and their least preferred choice (ranked as \#20) had the smallest weight $(=1)$.

\section{Additional file}

Additional file 1: Focus group interview protocol.

\section{Competing interests}

The authors declare that they have no competing interests.

\section{Acknowledgements}

This publication is the result of research sponsored by Alaska Sea Grant with funds from the National Oceanic and Atmospheric Administration Office of Sea Grant, Department of Commerce, under grant no. NA06OAR4170013 (project no. R/72-02), and from the University of Alaska with funds appropriated by the state. The author thanks ISER research associate Meghan Wilson and ISER research assistants Robyn Miller and Kate Sanders. The author also thanks the participants of the study and the community members of the five study communities who facilitated the research.

Received: 4 September 2014 Accepted: 27 March 2015

Published online: 16 July 2015

\section{References}

Acheson, James. 1981. The Anthropology of Fishing. Annual Review of Anthropology 10: 275-316.

Appadurai, Arjun. 1996. Modernity at Large: Cultural Dimensions of Globalization. Minneapolis: University of Minnesota Press.

Arbo, P, and B Hersoug. 1997. The globalization of the fishing industry and the case of Finnmark. Marine Policy 21(2): 121-142. doi:10.1016/s0308-597x(97)83224-1.

Bjarnason, T, and T Thorlindsson. 2006. Should I stay or should I go? Migration expectations among youth in Icelandic fishing and farming communities. Journal of Rural Studies 22(3): 290-300. doi:10.1016/j.jrurstud.2005.09.004.

Bourdieu, Pierre. 1977. Outline of a Theory of Practice. Cambridge: Cambridge University Press.

Bourdieu, Pierre. 1986. The Forms of Capital. In Handbook of Theory and Research for the Sociology of Education, ed. J Richardson, 241-258. New York: Greenwood.

Bye, Linda Marie. 2009. 'How to be a rural man': Young men's performances and negotiations of rural masculinities. Journal of Rural Studies 25(3): 278-288. doi:10.1016/j.jrurstud.2009.03.002.

Byun, Soo-yong, Judith L Meece, Matthew J Irvin, and Bryan C Hutchins. 2012. The Role of Social Capital in Educational Aspirations of Rural Youth. Rural Sociology 77(3): 355-379. doi:10.1111/j.1549-0831.2012.00086.x.

Carothers, Courtney. 2008. Rationalized Out: Discourses and Realities of Fisheries Privatization in Kodiak, Alaska. In Enclosing the Fisheries: People, Places, and Power, ed. Marie E Lowe and Courtney Carothers, 55-74. Betheda, MD: American Fisheries Society.

Corbett, Michael. 2004. "It Was Fine, if You Wanted to Leave": Educational Ambivalence in a Nova Scotian Coastal Community 1963-1998. Anthropology and Education Quarterly 35(4): 451-417.

Corbett, Michael. 2005. Rural Education and Out-Migration: The Case of a Coastal Community. Canadian Journal of Education / Revue canadienne de l'éducation 28(1/2): 52-72.

Corbett, Michael. 2006. What I Might Have Said: Rural Education and Globalization. Our Schools, Our Selves 16(1): 109-119.

Corbett, Michael. 2007a. All kinds of potential: Women and out-migration in an Atlantic Canadian coastal community. Journal of Rural Studies 23(4): 430-442. doi:10.1016/j.jrurstud.2006.12.001.

Corbett, Michael. 2007b. Learning to Leave. Fernwood Publishing Co.: Black Point, Nova Scotia.

Dahlström, Margareta. 1996. Young women in a male periphery - Experiences from the Scandinavian north. Journal of Rural Studies 12(3): 259-271. http://doi:10.1016/0743-0167(96)00018-6

Donkersloot, Rachel. 2012. Gendered and generational experiences of place and power in the rural Irish landscape. Gender, Place \& Culture 19(5): 578. doi:10.1080/0966369X.2011.610095.

Eisenhauer, B, R Krannich, and D Blahna. 2000. Attachments to Special Places on Public Lands: An Analysis of Activities, Reasons for Attachments, and Community Connections. Society and Natural Resources 13(5): 421-441.

Elder, Glen H, and Valarie King. 1996. Attachment to Place and Migration Prospects. Journal of Research on Adolescence 6(4): 397-425.

Ervin, Alexander. 2005. Applied Anthropology: Tools and Perspectives for Contemporary Practice. Boston: Pearson.

Eypórsson, E. 1997. Coastal communities and ITQ management. The case of Icelandic fisheries. In Social Implications of Quota Systems in Fisheries, ed. G Pálsson and G Pétursdóttir, 107-120. Copenhagen: TemaNord.

Froerer, Peggy, and Anna Portisch. 2012. Introduction to the Special Issue: Learning, Livelihoods, and Social Mobility. Anthropology \& Education Quarterly 43(4): 332-343. doi:10.1111/j.1548-1492.2012.01188.x.

Giddens, A. 1981. A Contemporary Critique of Historical Materialism. London: Macmillan.

Giddens, A. 1984. The Constitution of Society. Cambridge: Polity Press.

Giddens, Anthony. 1991. The Consequences of Modernity. Stanford: Stanford University Press.

Glendinning, Anthony, Mark Nuttall, Leo Hendry, Marion Kloep, and Sheila Wood. 2003. Rural communities and well-being: a good place to grow up? The Sociological Review 51(1): 129-156. doi:10.1111/1467-954X.00411. 
Hamilton, Lawrence C, and Carole L Seyfrit. 1993. Town-Village Contrasts in Alaskan Youth Aspirations. Arctic 46(3): 255-263. Hamilton, Lawrence C, and Carole L Seyfrit. 1994. Resources and Hopes in Newfoundland. Society and Natural Resources 7(6): 561-578.

Hanson, AJ, Leonard Kasdan, and Cynthia Lamson. 1984. Atlantic Fisheries and Coastal Communities: Fisheries Decision-Making Case Studies. In Atlantic Fisheries and Coastal Communities: Problems and Prospects, ed. Cynthia Lamson and AJ Hanson, 235-241. Halifax, Nova Scotia: Dalhousie Ocean Studies Programme.

Heggen, Kåre. 2000. Marginalisation: on the fringe of the periphery — Youth as a risky life stage? Young 8(2): 45-62. doi:10.1177/110330880000800203.

Howe, EL. 2009. Patterns of migration in arctic Alaska. Polar Geography 32(1-2): 69-89.

Huskey, L. 2009. Community Migration in Alaska's North: The Places People Stay and the Places They Leave. Polar Geography 32(1-2): 1-14.

Huskey, Lee, Matthew Berman, and Alexandra Hill. 2004. Leaving home, returning home: Migration as a labor market choice for Alaska Natives. Annals of Regional Science 38(1): 75-92.

Ingram, Nicola. 2009. Working-Class Boys, Educational Success and the Misrecognition of Working-Class Culture. British Journal of Sociology of Education 30(4): 421-434. doi:10.1080/01425690902954604.

Jentoft, Svein. 1993. Dangling Lines, The Fisheries Crisis and the Future of Coastal Communities: The Norwegian Experience. St. John's, Newfoundland, Canada: Institute of Social and Economic Research, Memorial University of Newfoundland.

Jentoft, Svein. 2000. The community: a missing link of fisheries management. Marine Policy 24(1): 53-60. http:// dx.doi.org/10.1016/S0308-597X(99)00009-3.

Jentsch, Birgit. 2006. Youth Migration From Rural Areas: Moral Principles to Support Rural Youth. Sociologica Ruralis 46(3): 229-240. Jones, G. 1999. The Same People in the Same Places? Socio-Spatial Identities and Migration in Youth. Sociology 33: 1-22.

Karlsdóttir, Anna. 2008. Not Sure About the Shore! Transformation Effects of Individual Transferable Quotas on Iceland's Fishing Economy and Communities. In Enclosing the Fisheries: People, Places, and Power, ed. Marie E Lowe and Courtney Carothers, 99-118. Bethesda, MD: American Fisheries Society.

Kleinfeld, Judith, and Justin J Andrews. 2006. The Gender Gap in Higher Education in Alaska. Arctic 59(4): 428-434.

Knapp, Gunnar, and Marie E Lowe. 2007. Economic and social impacts of BSAl crab rationalization on the communities of King Cove, Akutan, and False Pass. Anchorage, Alaska: Institute of Social and Economic Research.

Kreuger, RA. 1988. Focus Groups: A Practical Guide for Applied Research. Newbury Park, CA: Sage.

Langdon, Steve J. 2008. The Community Quota Program in the Gulf of Alaska: A Vehicle for Alaska Native Sustainability? In Enclosing the Fisheries: People, Places, and Power, ed. Marie E Lowe and Courtney Carothers, 155-194. Bethesda, MD: American Fisheries Society.

Looker, D, and P Dwyer. 1998. Education and Negotiated Reality: Complexities Facing Rural Youth in the 1990s. Journal of Youth Studies 1: 5-22.

Loring, Philip, and Hannah Harrison. 2013. "That's what opening day is for:" social and cultural dimensions of (not) fishing for salmon in Cook Inlet, Alaska. Maritime Studies 12(1): 12-12. doi:10.1186/2212-9790-12-12.

Lowe, Marie E. 2008. Crab Rationalization and Potential Community Impacts of Vertical Integration in Alaska's Fisheries. In Enclosing the Fisheries: People, Places, and Power, ed. Marie E Lowe and Courtney Carothers, 119-154. Bethesda, MD: American Fisheries Society.

Lowe, Marie E. 2010. Contemporary Rural-urban Migration in Alaska. Alaska Journal of Anthropology 8(2): 71-88.

Lowe, Marie E, and Courtney Carothers. 2008. Enclosing the Fisheries: People, Places, and Power. Bethesda, MD: American Fisheries Society.

Mansfield, Becky. 2004. Neoliberalism in the oceans: "rationalization", property rights, and the commons question. Geoforum 35(3): 313-326. doi:10.1016/j.geoforum.2003.05.002

Martin, Stephanie. 2009. The effects of female out-migration on Alaska villages. Polar Geography 32(1-2): 61-67.

Martin, Stephanie, Mary Killorin, and Steve Colt. 2008. Fuel Costs, Migration, and Community Viability. Anchorage: Institute of Social and Economic Research.

Massey, Doreen. 1995. The Conceptualisation of Place. In A Place in the World? Places, Cultures and Globalisation, ed. D Massey and P Jess. Oxford: Oxford Open University Press/Oxford University Press.

McCay, Bonnie J. 1995. Social and Ecological Implications of ITQs: An Overview. Ocean and Coastal Management 28(1-3): 3-22.

McCay, Bonnie J. 2000. Sea Changes in Fisheries Policy: Contributions from Anthropology. In State and Community in Fisheries Management, ed. E Paul Durrenberger and Thomas D King, 201-217. Westport, CT: Bergin and Garvey.

McGrath, Brian. 2001. "A problem of resources": defining rural youth encounters in education, work \& housing. Journal of Rural Studies 17(4): 481-495. doi:10.1016/S0743-0167(01)00023-7.

Muilu, Toivo, and Jarmo Rusanen. 2003. Rural young people in regional development-the case of Finland in 1970-2000. Journal of Rural Studies 19(3): 295-307. doi:10.1016/s0743-0167(03)00003-2.

Nadel-Klein, J, and DL Davis. 1988. Introduction: Gender in the maritime arena. In To Work and to Weep, ed. DL Davis and J Nadel-Klein, 1-17. St. John's: Newfoundland: Memorial.

Ommer, Rosemary. 2007. Coasts under stress: restructuring and social-ecological health, vol. Book, Whole. Montreal: McGill-Queen's University Press.

Orbach, Michael. 1977. Hunters, Seamen, and Entrepreneurs: The Tuna Seinermen of San Diego. Berkeley: University of California Press.

Pálsson, G, and G Pétursdóttir. 1997. Social Implications of Quota Systems in Fisheries. Copenhagen: TemaNord.

Paulgaard, Gry. 2002. Local identities in a 'globalised world'. Young 10(3-4): 95-107. doi:10.1177/110330880201000307.

Pretty, Grace, Paul Bramston, Jeff Patrick, and Wendy Pannach. 2006. The Relevance of Community Sentiments to Australian Rural Youths' Intention to Stay in Their Home Communities. American Behavioral Scientist 50(2): 226-240. doi:10.1177/0002764206290636.

Putnam, Robert D. 2007. E Pluribus Unum: Diversity and Community in the Twenty-first Century The 2006 Johan Skytte Prize Lecture. Scandinavian Political Studies 30(2): 137-174.

Rasmussen, Rasmus Ole. 2009. Gender and Generation: Perspectives on Ongoing Social and Environmental Changes in the Arctic. Signs 34(3): 524-532. doi:10.1086/593342.

Rasmussen, Rasmus Ole. 2011. Megatrends, ed. TemaNord: Nordic Council of Ministers. 
Reedy-Maschner, Katherine L. 2010. Aleut Identities. Montreal: McGill-Queen's University Press.

Rosvold, Eric. 2007. Graying of the Fleet: Community Impacts from Asset Transfers. In Alaska's Fishing Communities: Harvesting the Future, ed. Paula Cullenberg. Anchorage, Alaska: Alaska Sea Grant College Program.

Rygaard, Jette. 2003. Youth Culture, Media and Globalization Processes in Greenland. Young 11(4): 291-308. doi:10.1177/11033088030114001.

Skaptadóttir, Unnur Dís. 1996. Gender Construction and Diversity in Icelandic Fishing Communities. Anthropologica 38(2): 271-287.

Skaptadóttir, Unnur Dís. 2000. Women Coping With Change in An Icelandic Fishing Community. Women's Studies International Forum 23(3): 311-321.

Waara, Peter, universitet Uppsala, vetenskapsområdet Humanistisk-samhällsvetenskapliga, didaktik och utbildningsstudier Institutionen för pedagogik, and utbildningsvetenskaper Fakulteten för. 2002. At the end of the world - Young people in the Barents area. Young 10(3-4): 2-11. doi:10.1177/110330880201000301.

Wiborg, Agnete. 2003. Between Mobility and Belonging: Out-migrated Young Students' Perspectives on Rural Areas in North Norway. Acta Borealia 20(2): 147-168. doi:10.1080/08003830310003155.

Windisch-Cole, Brigitta. 2009. Alaska's Rural Population and School Population Trends. Anchorage: State of Alaska Division of Community and Regional Affairs.

Yodanis, Carrie L. 2000. Constructing Gender and Occupational Segregation: A Study of Women and Work in Fishing Communities. Qualitative Sociology 23: 3.

Zipin, Lew, Sam Sellar, Marie Brennan, and Trevor Gale. 2015. Educating for Futures in Marginalized Regions: A sociological framework for rethinking and researching aspirations. Educational Philosophy and Theory 47(3): 227-246. doi:10.1080/00131857.2013.839376.

Submit your manuscript to a SpringerOpen ${ }^{\circ}$ journal and benefit from:

- Convenient online submission

- Rigorous peer review

- Immediate publication on acceptance

- Open access: articles freely available online

- High visibility within the field

- Retaining the copyright to your article 